\title{
Stray current induced corrosion of steel fibre reinforced concrete
}

\section{Kangkang Tang}

kangkangtang@gmail.com

Faculty of Science and Engineering, University of Wolverhampton, UK

\section{Abstract}

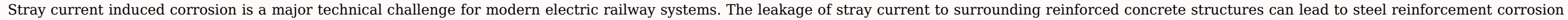

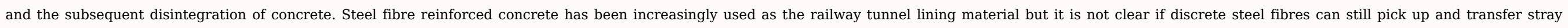

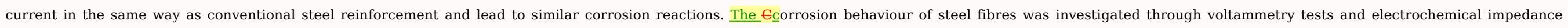

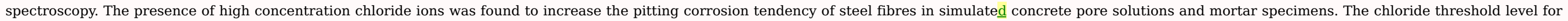
corrosion of steel fibres in concrete is approximately $4 \% \mathrm{NaCl}$ (by mass of cement) which is significantly higher than that of conventional steel reinforcement.

Keywords: Steel fibre reinforced concrete; EIS; Cyclic voltammetry; Potentiostatic; Passivity; Pitting corrosion

\section{List of notations}

$\alpha_{a^{\prime}} \alpha_{c}$ Constant values (V)

$A$ Exposed anode area $\left(\mathrm{cm}^{2}\right)$

$\beta_{a}, \beta_{b}$ Anodic and cathodic Tafel constants/gradients

$C_{f}$ Capacitance of mortar $\left(\mathrm{S}_{\cdot} \cdot \mathrm{S}^{\mathrm{n}} \cdot \mathrm{cm}={ }^{2}\right)$

$C_{d l}$ Capacitance represents the layer between the solution and the steel surface. Faradaic charge transfer reaction on the steel surface $\left(\mathrm{S}_{\bullet-}^{*} \mathrm{~s}^{\mathrm{n}} \bullet \mathrm{cm}^{=2}\right)$

CR Corrosion rate (mm/year)

$E W$ Mass of metal that will be oxidized by the passage of one Faraday of electric charge (27.925 for steel)

$E_{e, a} E_{e, c}$ Anodic and cathodic equilibrium potentials (V)

$E_{\text {corr }}$ Corrosion potential (V)

$I$ Measured current from the circuit or the net electron flow (A)

$I_{a}, I_{C}$ Anodic and cathodic currents (A)

$I_{0, a}, I_{O, c}$ Anodic and cathodic exchange currents (A)

$I_{\text {corr }}$ Corrosion current (A)

$i_{\text {corr }}$ Corrosion current density $\left(\mathrm{A} / \mathrm{cm}^{2}\right)$

$K$ Constant value: $3.27 \_\times 10={ }^{3}\left(\mathrm{~mm} \bullet_{-} \mathrm{g} / \mathrm{\mu A}{ }_{-} \mathrm{cm}-\mathrm{y}\right.$ year $)$

$L$ Distance between substations $(\mathrm{km})$ 
$\eta_{e, a}, \eta_{e, c}$ Anodic and cathodic overpotentials (V) from the equilibrium potential $E_{e, a}$ and $E_{e, c}$

$\rho$ Density $\left(7.8 \mathrm{~g} / \mathrm{cm}^{3}\right.$ for steel)

$r_{R}$ Resistance of the running tracks $(\Omega / \mathrm{km})$

$r_{T}$ Track-earth resistance $(\Omega \cdot \mathrm{km})$

$R_{S}$ Resistance of the solution $\left(\mathrm{k} \Omega \star \mathrm{cm}^{2}\right)$

$R_{f}$ Resistance of mortar layer $\left(\mathrm{k} \Omega * \mathrm{~cm}^{2}\right)$

$R_{c t}$ Charge transfer resistance of the steel $\left(\mathrm{k} \Omega \cdot \mathrm{cm}^{2}\right)$

$\theta$ Phase shift (radian)

$W$ Warburg diffusion element $\left(\mathrm{S} \cdot \mathrm{s}^{1 / 2} \cdot \mathrm{cm}^{=2}\right)$

\subsection{Introduction}

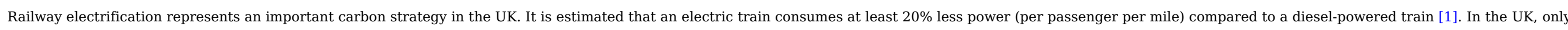

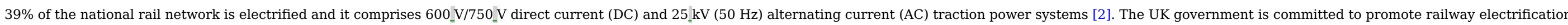

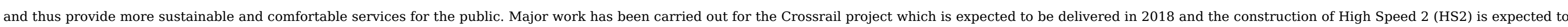

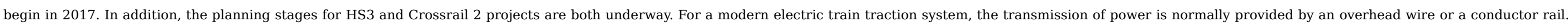

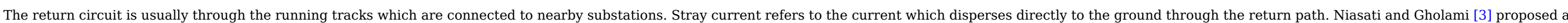

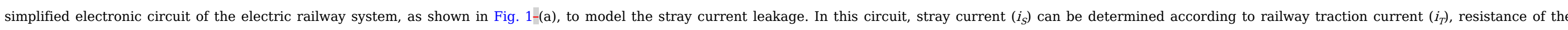

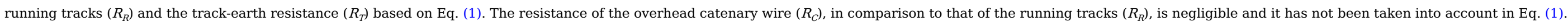
$i_{S}=\frac{R_{R} i_{T}}{R_{T}+R_{R}+R_{S}}$
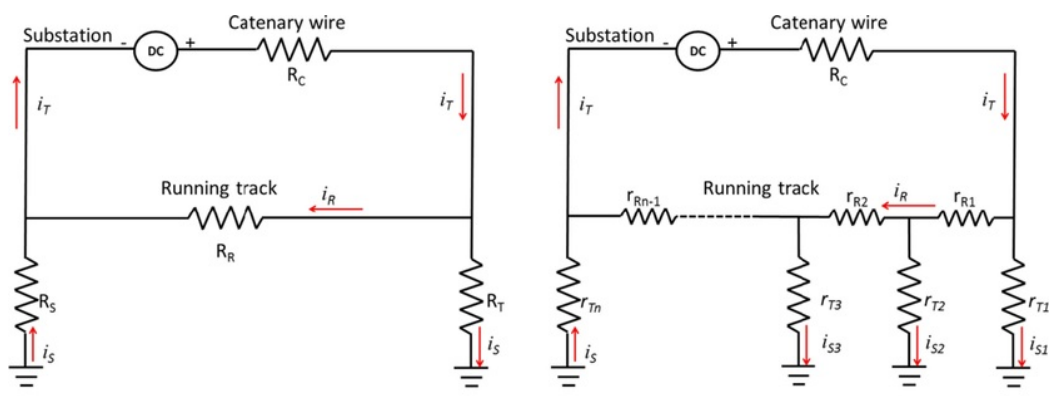

(a) Single leakage of stray current

(b) Multiple leakages of stray current

Fig. 1.Fig. 1 Equivalent electronic circuits of stray current formation]

alt-text: Fig. 1

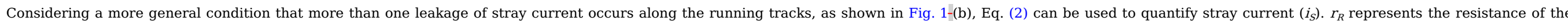
running tracks and $r_{T}$ represents the track-earth resistance [4].

$i_{S}=\frac{1}{12} i_{T} \frac{r_{R}}{r_{T}} L^{2}$ 


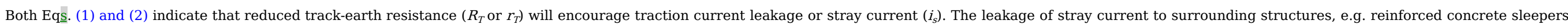

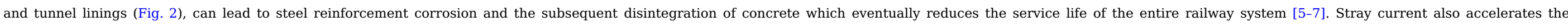

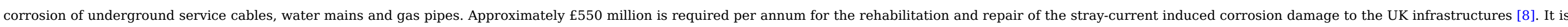

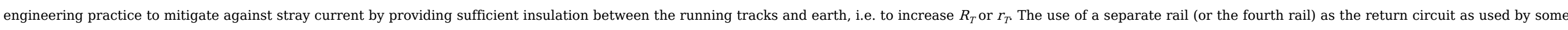

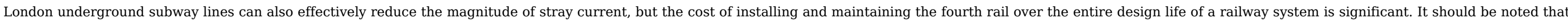

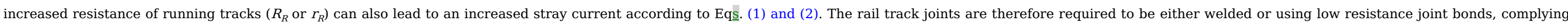

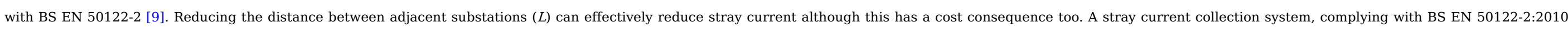
[9], can capture the stray current and return it back to substations through a return earth wire [10]. This can also be taken as an effective stray current mitigation method.

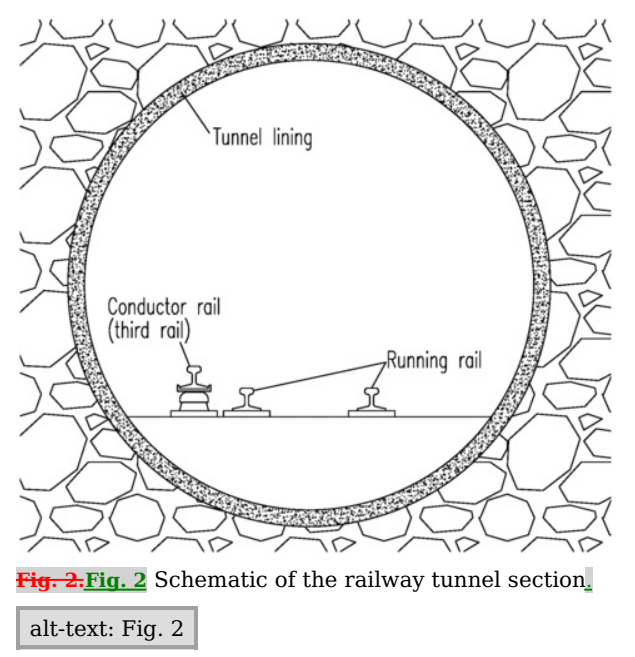

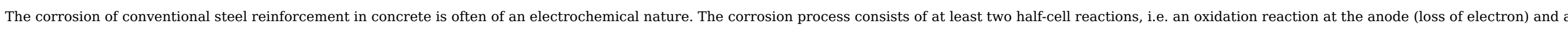
reduction reaction at the cathode (gain of electron) [11]. The anodic reaction is normally iron dissolution:

$\mathrm{Fe} \rightarrow \mathrm{Fe}^{2+}+2 e^{-}$

The cathodic reaction can be oxygen reduction:

$\mathrm{O}_{2}+2 \mathrm{H}_{2} \mathrm{O}+4 e^{-} \rightarrow 4 \mathrm{OH}^{-}$

The cathodic reaction can also be water reduction, in the absence of oxygen: $2 \mathrm{H}_{2} \mathrm{O}+2 e^{-} \rightarrow 2 \mathrm{OH}^{-}+\mathrm{H}_{2}$

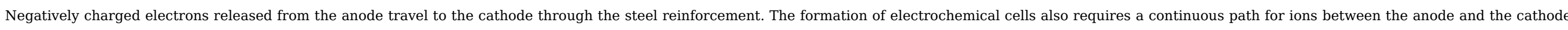

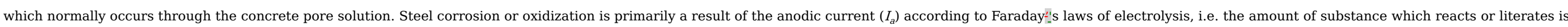

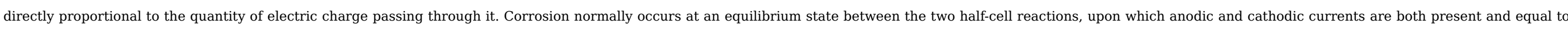
each other, namely the corrosion current ( $\left.I_{\text {corr }}\right)$ [12]. The steel corrosion rate $(C R)$ can be determined according to Eq. (6) [13]:

$C R=\frac{K I_{\text {corr }} E W}{\rho A}$

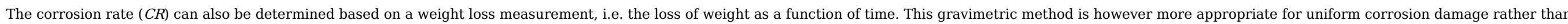
pitting corrosion (or pitting) which is a common form of steel reinforcement corrosion but without inducing significant mass change [14]. 


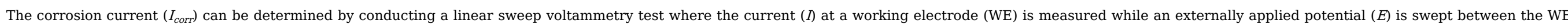

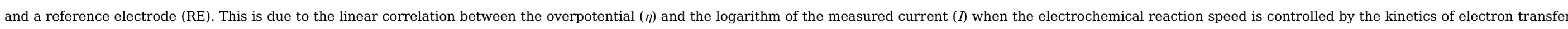
[15]. This correlation is also called Tafel behaviour which can be described as Eq. (7):

$\eta_{a}=\mathrm{E}-E_{e, a}=\alpha_{a}+\beta_{a} \ln I_{a}$

Analogously, Tafel behaviour for the cathodic reaction can be described as:

$\eta_{c}=\mathrm{E}-E_{e, c}=\alpha_{c}-\beta_{c} \ln I_{c}$

Eqs. (7) and (8) can be written in an exponential format [16]:

$I_{a}=I_{0, a} \exp \left(\frac{\mathrm{E}-E_{e, a}}{\beta_{a}}\right)$

$I_{c}=I_{0, c} \exp \left(-\frac{\mathrm{E}-E_{e, c}}{\beta_{c}}\right)$

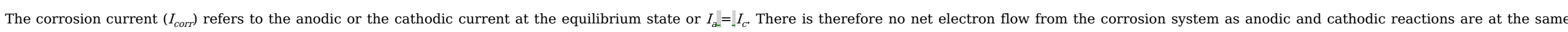
speed. Eq. (11) or Butler-Volmer equation can be used to calculate the net electron flow ( $I$ ) of an electrochemical cell [17]:

$$
I=I_{a}-I_{c}=I_{c o r r}\left[\exp \left(\frac{\mathrm{E}-E_{\text {corr }}}{\beta_{a}}\right)-\exp \left(-\frac{\mathrm{E}-E_{\text {corr }}}{\beta_{c}}\right)\right]
$$

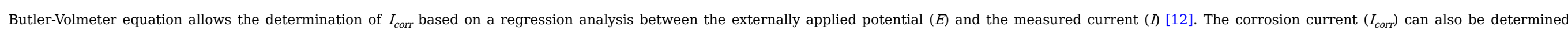
according to Stern-Geary equation (Eq. (12)) which is a mathematically reduced form of Butler-Volmeter equation [18].

$$
I_{\text {corr }}=\frac{\beta_{a} \beta_{c}}{\beta_{a}+\beta_{c}} \times \frac{1}{R_{p}}
$$

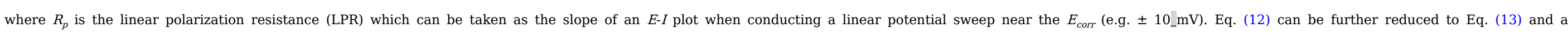
constant $B$ value can be used to quickly determine the corrosion current $\left(I_{\text {corr }}\right)[11]$.

$I_{\text {corr }}=\frac{B}{R_{p}}$

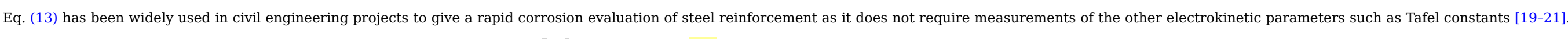

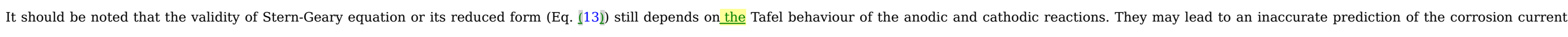
$\left(I_{\text {corr }}\right)$ for a diffusion-controlled (or diffusion-limited) corrosion reaction. In this work, a regression analysis based on Butler-Volmer equation (Eq. (11)) was conducted to determine $I_{\text {corr }}$

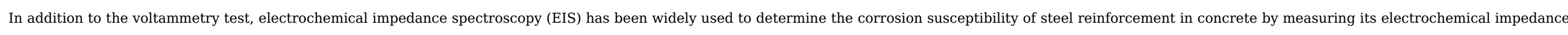

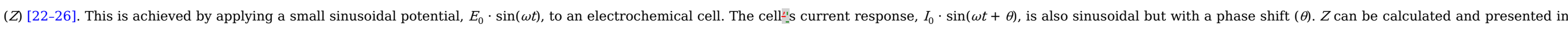
following form [27]:

$Z=\frac{E}{I}=\frac{E_{0} \cdot \sin (\omega t)}{I_{0} \cdot \sin (\omega t+\theta)}=\frac{E_{0}}{I_{0}}(\cos \theta+j \cdot \sin \theta)$

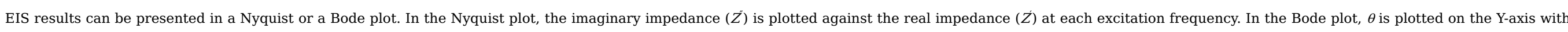

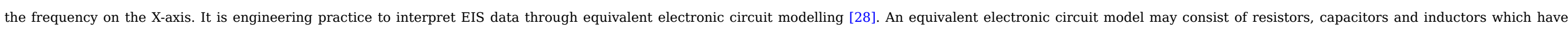

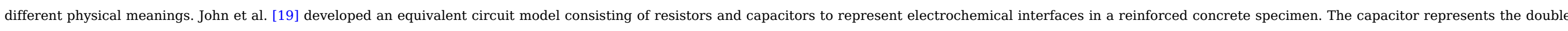

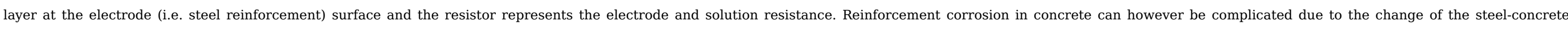

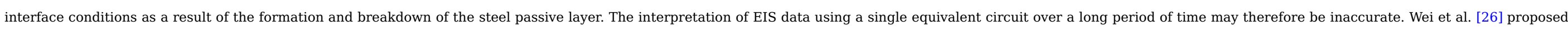




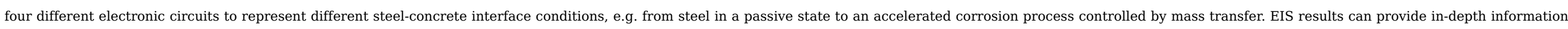
on charge transfer kinetics such as charge transfer resistance $\left(R_{c t}\right)$ which is directly relevant to the susceptibility of steel pitting corrosion in concrete.

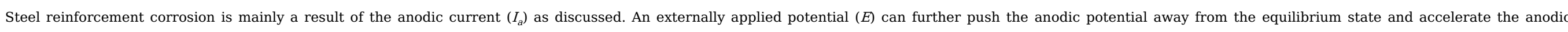

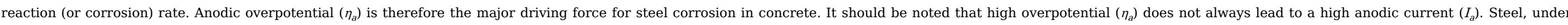

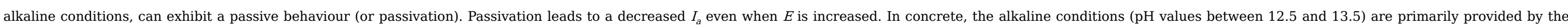

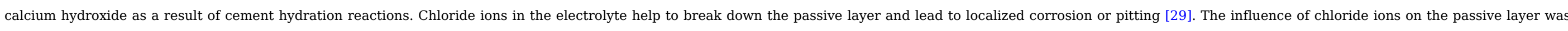

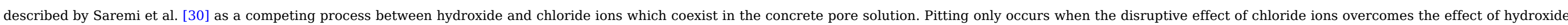
ions which stabilize the surface lattice of steel.

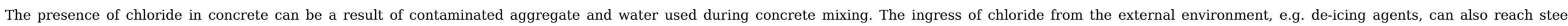

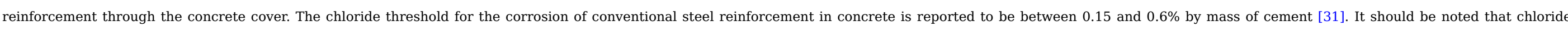

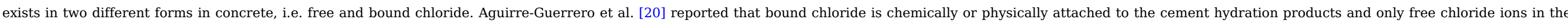

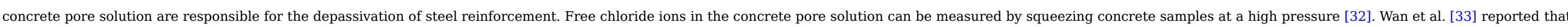

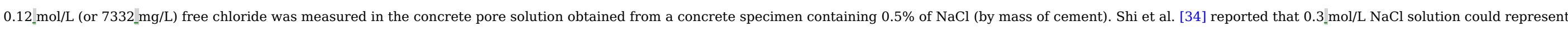

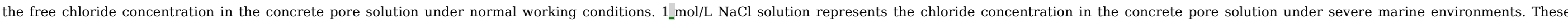

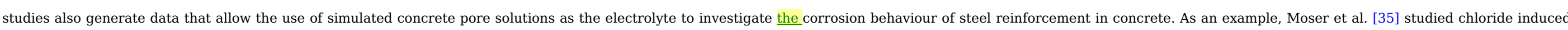

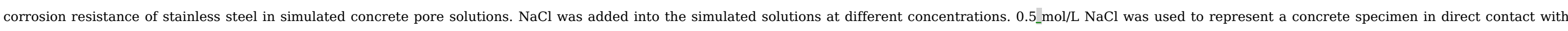

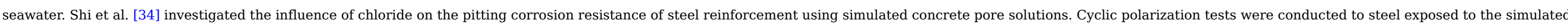
pore solutions using various $\mathrm{NaCl}$ concentrations, i.e. $0.1,0.3$ and $1 \_\mathrm{mol} / \mathrm{L}$. 1_mol/L represents severe marine environments for characterization of pitting corrosion resistance.

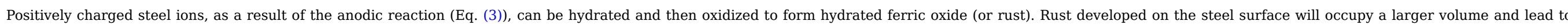

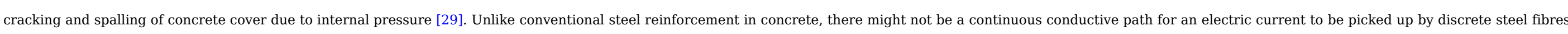

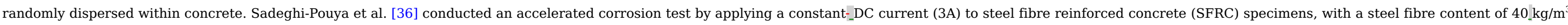

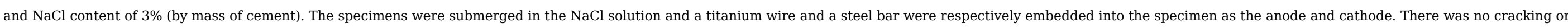

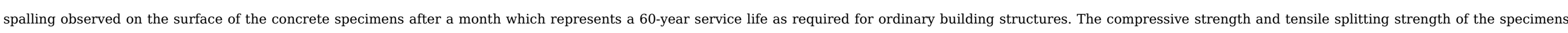

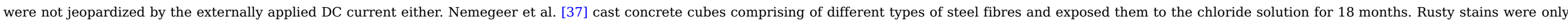
identified on the surface of concrete containing steel fibres although no detrimental effect on the compressive strength of the concrete was observed.

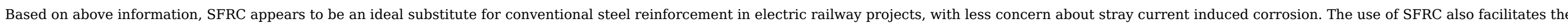

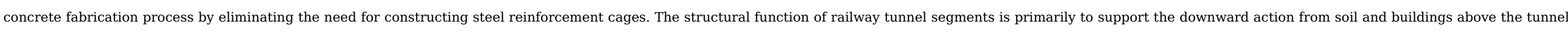

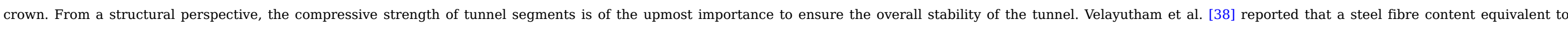

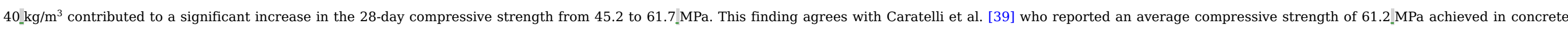

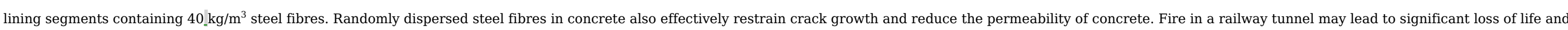

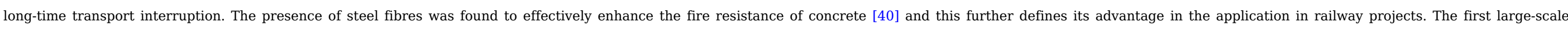
application of SFRC segments in railway projects, without using any conventional steel reinforcement, was the 20_km twin-tube sections of the Channel Tunnel Rail Link project [41].

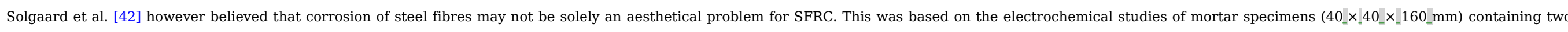

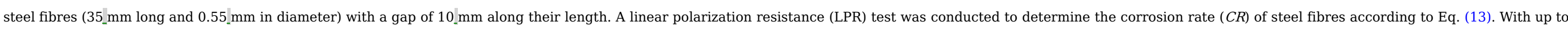

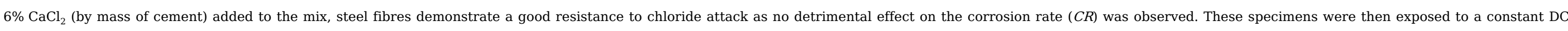

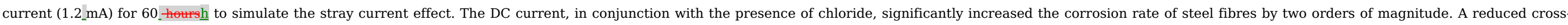




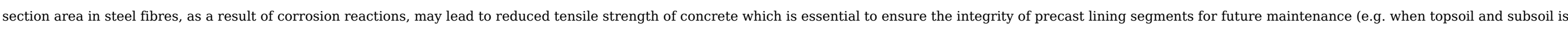

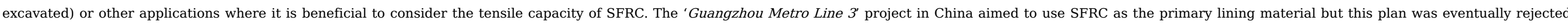

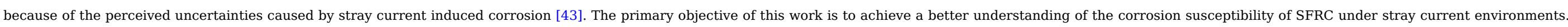

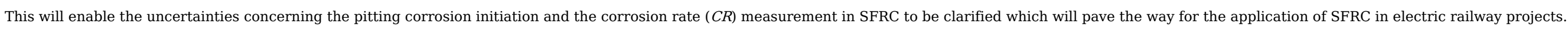

\subsection{Experimental procedures}

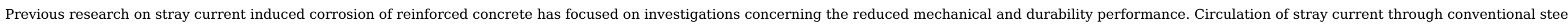

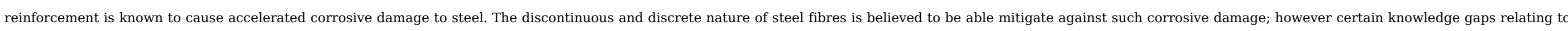
SFRC have become apparent since the construction and operation of the Channel Tunnel when it was first used as the primary railway tunnel lining material

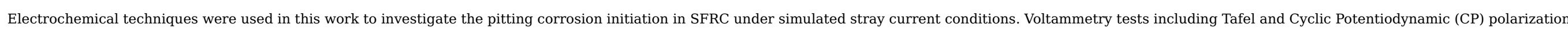

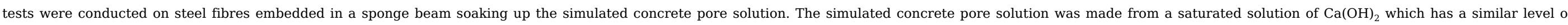

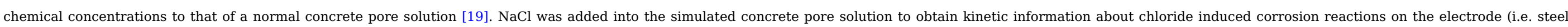

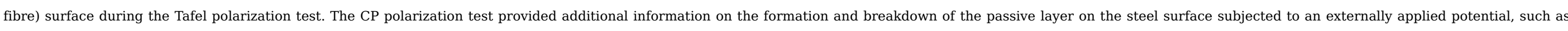

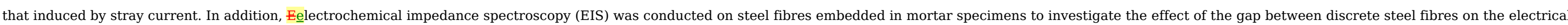

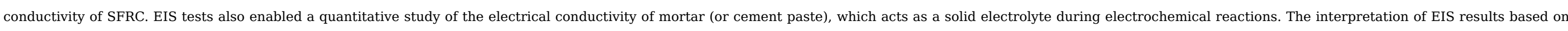

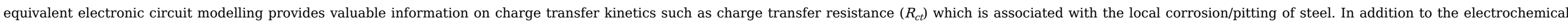

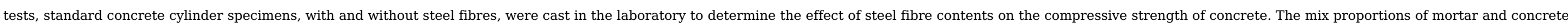
specimens used in this work match those previously used in the Channel Tunnel project as the tunnel lining material [39].

\subsubsection{Steel fibre corrosion tests in simulated concrete pore solution}

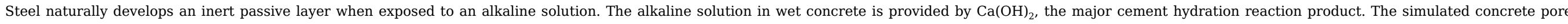

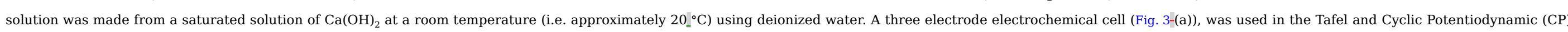

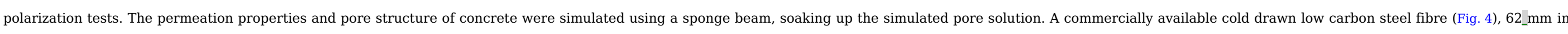

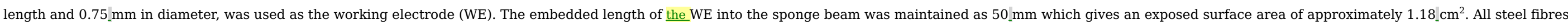

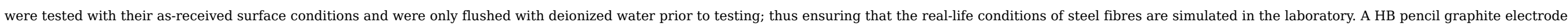

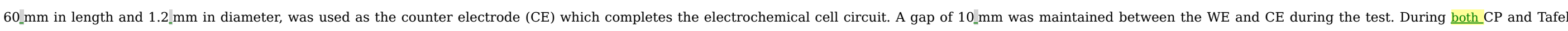

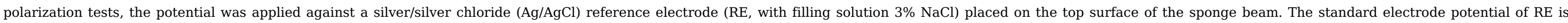
$250 \_ \pm 5[\mathrm{mV} \text { against a Standard Hydrogen Electrode (SHE). }$

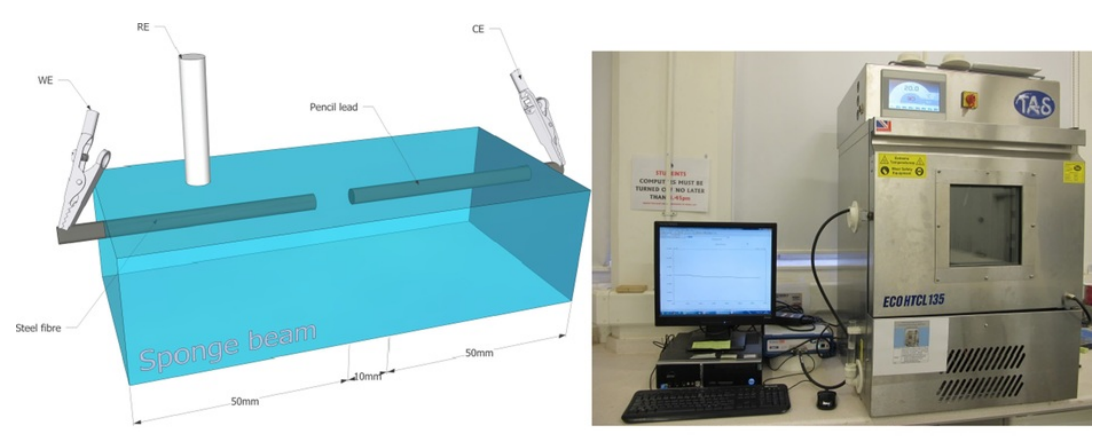

(a) Schematic of the electrochemical cell

(b) Environmental chamber 


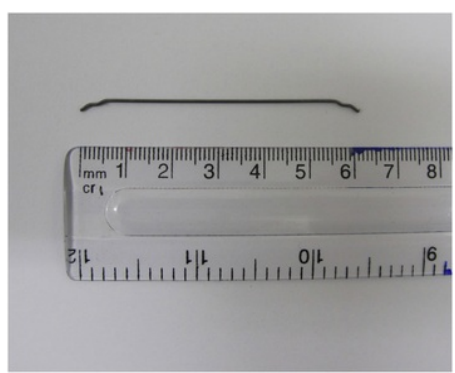

Fig. 4.Fig. 4 Steel fibre used in this work (DRAMIX 4D 80/60BG),

\section{alt-text: Fig. 4}

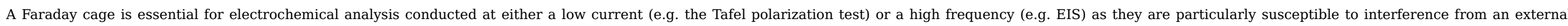

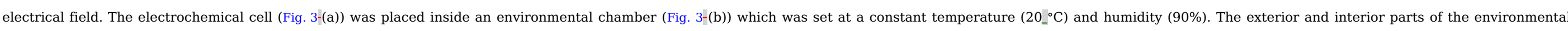

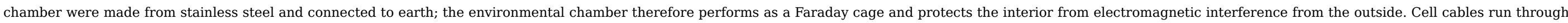
a hole in the chamber wall.

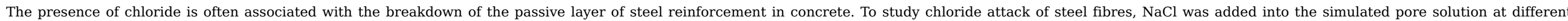

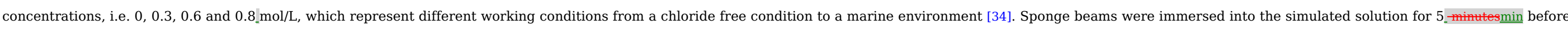

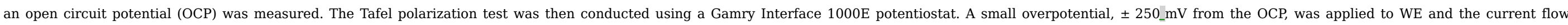

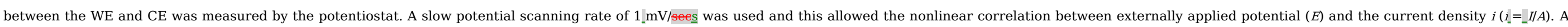

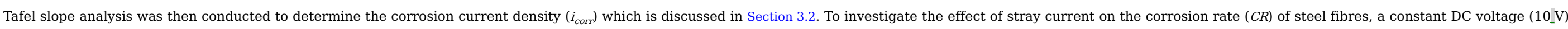
was applied to the cell using freshly prepared electrodes and electrolytes. The Tafel polarization test was then conducted and results are discussed in Section 3.2 as well.

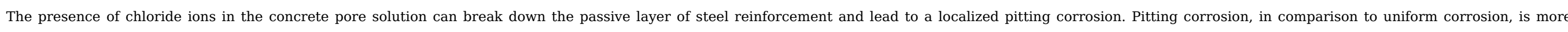

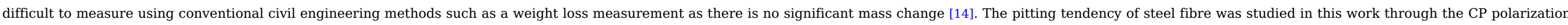

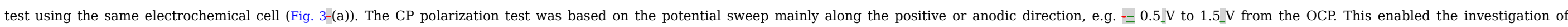

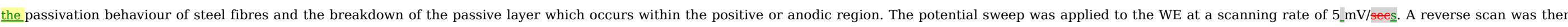

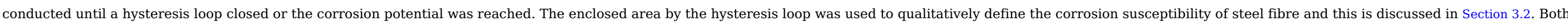

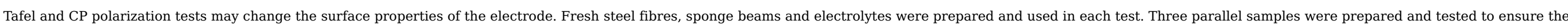
repeatability of the results.

\subsubsection{SFRC mixes}

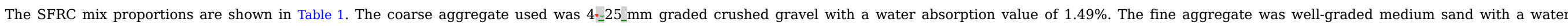

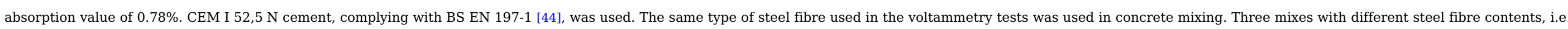

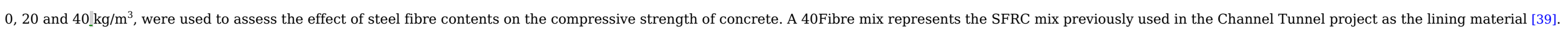




\begin{tabular}{|c|c|c|c|c|c|c|}
\hline Concrete mixes & $\begin{array}{l}\text { CEM I } 52,5 \\
\left(\mathrm{~kg} / \mathrm{m}^{3}\right)\end{array}$ & Free W/C & $\begin{array}{c}\text { Sand }(0--4 \text { - mm }) \\
\left(\mathrm{kg} / \mathrm{m}^{3}\right)\end{array}$ & $\begin{array}{c}\text { Gravel }(4--25-m m) \\
\left(\mathrm{kg} / \mathrm{m}^{3}\right)\end{array}$ & $\begin{array}{l}\text { Steel fibre } \\
\left(\mathrm{kg} / \mathrm{m}^{3}\right)\end{array}$ & $\begin{array}{c}\text { Superplasticizer } \\
\left(\mathrm{kg} / \mathrm{m}^{3}\right)\end{array}$ \\
\hline 0Fibre & 480 & 0.35 & 845 & 869 & 0 & 4.8 \\
\hline 20Fibre & 480 & 0.35 & 845 & 869 & 20 & 4.8 \\
\hline 40Fibre & 480 & 0.35 & 845 & 869 & 40 & 4.8 \\
\hline
\end{tabular}

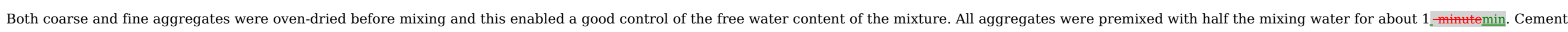

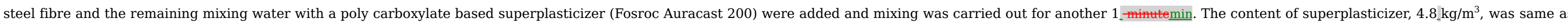

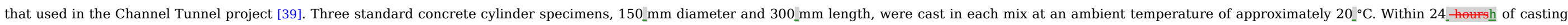

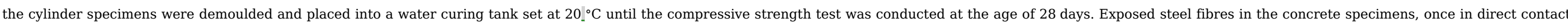
with the welded mesh panel inside the curing tank, may give rise to galvanic corrosion. To prevent such direct contact a plastic sheet was placed between the SFRC specimens and the mesh panel.

\subsubsection{Steel corrosion tests in mortar specimens}

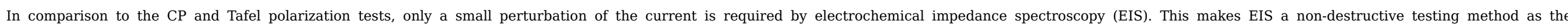

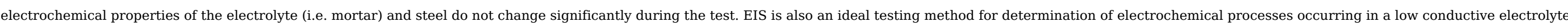
such as mortar and concrete [11].

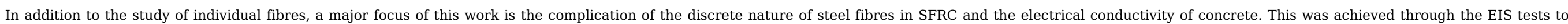

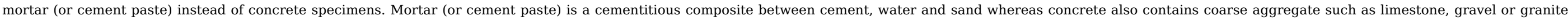

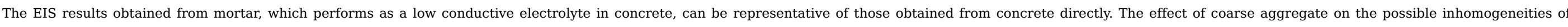
concrete subjected to an electrical field is an on-going area of research.

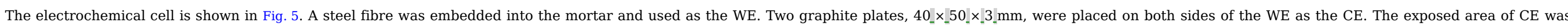

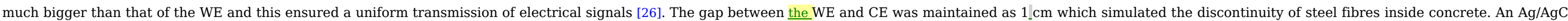

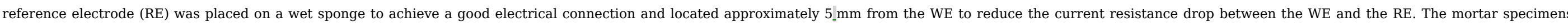

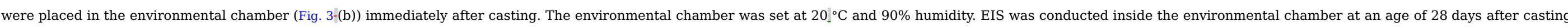
using the Gamry Interface 1000E potentiostat.

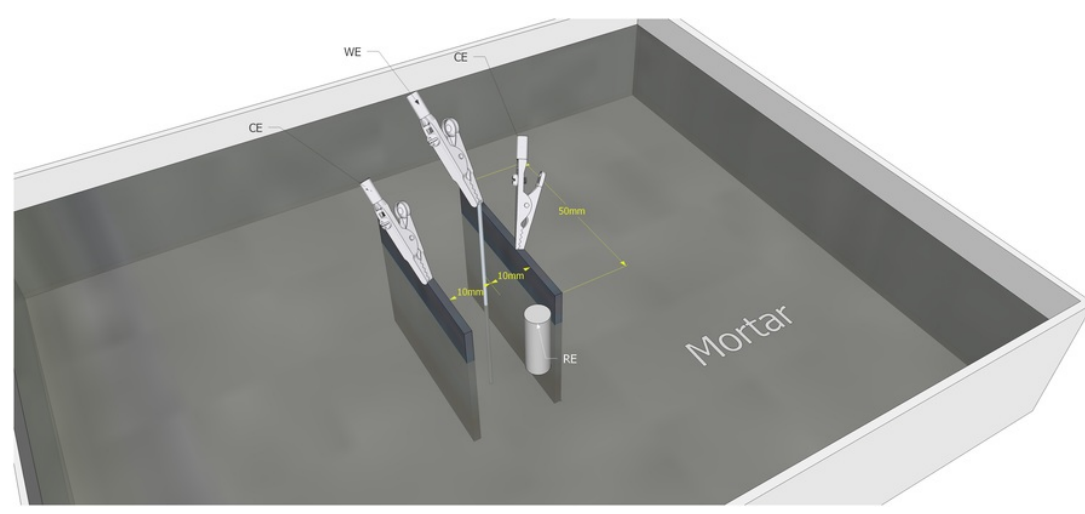

Fig. 5.Fig. 5 Schematic of the electrochemical cell used in EIS:

alt-text: Fig. 5 


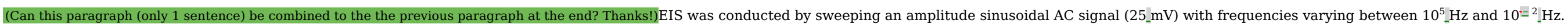

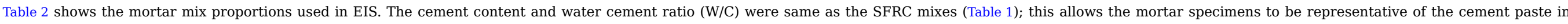

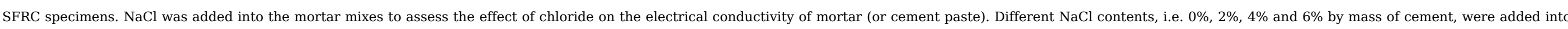

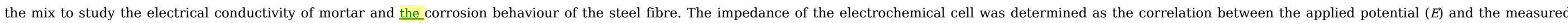
current $(l)$. The best fit results based on equivalent electronic circuit modelling are discussed in Section 3.3.

Table 2 Mortar mix proportions.

alt-text: Table 2

\begin{tabular}{|c|c|c|c|c|}
\hline Mortar mixes & $\begin{array}{l}\text { CEM I } 52,5 \\
\left(\mathrm{~kg} / \mathrm{m}^{3}\right)\end{array}$ & Free W/C & $\begin{array}{c}\text { Sand }\left(0_{--}^{-} 4 \text { mm }\right) \\
\left(\mathrm{kg} / \mathrm{m}^{3}\right)\end{array}$ & $\begin{array}{c}\mathrm{NaCl} \\
\left(\mathrm{kg} / \mathrm{m}^{3}\right)\end{array}$ \\
\hline $0 \% \mathrm{NaCl}$ & 480 & 0.35 & 1814 & 0 \\
\hline $2 \% \mathrm{NaCl}$ & 480 & 0.35 & 1814 & 9.6 \\
\hline $4 \% \mathrm{NaCl}$ & 480 & 0.35 & 1814 & 19.2 \\
\hline $6 \% \mathrm{NaCl}$ & 480 & 0.35 & 1814 & 28.8 \\
\hline
\end{tabular}

\subsection{Results and discussion}

\subsubsection{Compressive strength}

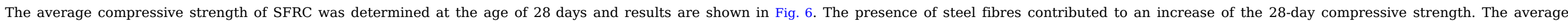
compressive strength of $40 \mathrm{Fibre} \mathrm{mix} \mathrm{(i.e.} 40 \_\mathrm{kg} / \mathrm{m}^{3}$ steel fibre) was 58.6_MPa which is $10 \%$ higher than the unreinforced concrete cylinders, $52.4 \_\mathrm{MPa}$.

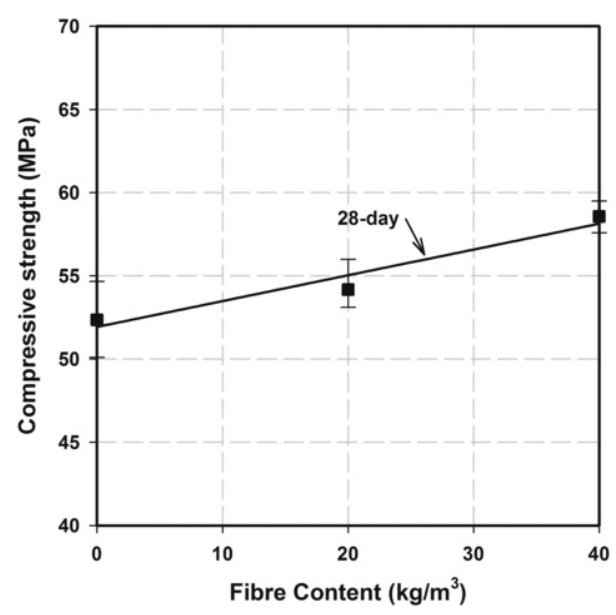

Fig. 6 SFRC compressive strength at the age of 28 days

alt-text: Fig. 6

\subsubsection{Steel fibre corrosion in simulated concrete pore solution}

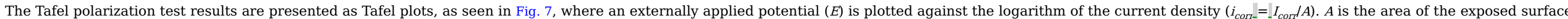




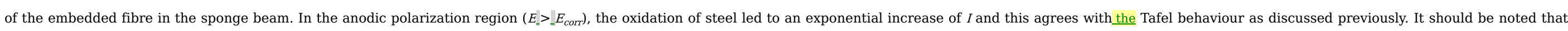

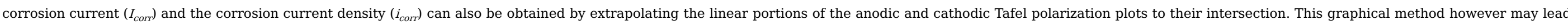

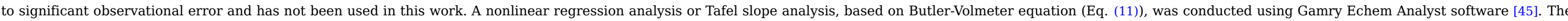

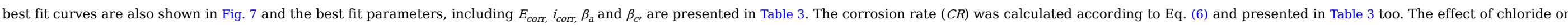

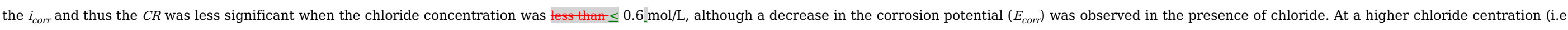
$0.8 \mathrm{~mol} / \mathrm{L}$ ), both the $i_{\text {corr }}$ and $C R$ increased by one order of magnitude in comparison to those obtained from the chloride free solution and this indicates a high risk of pitting corrosion.
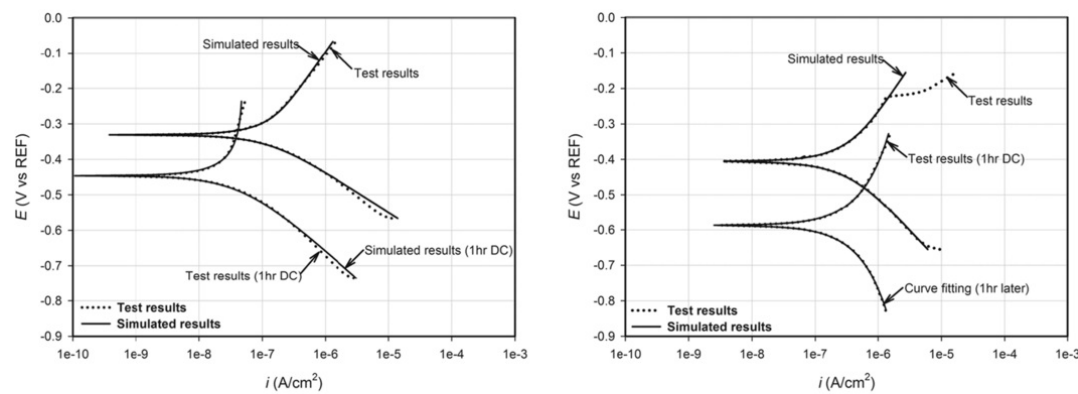

(a) $\mathrm{Ca}(\mathrm{OH})_{2}$

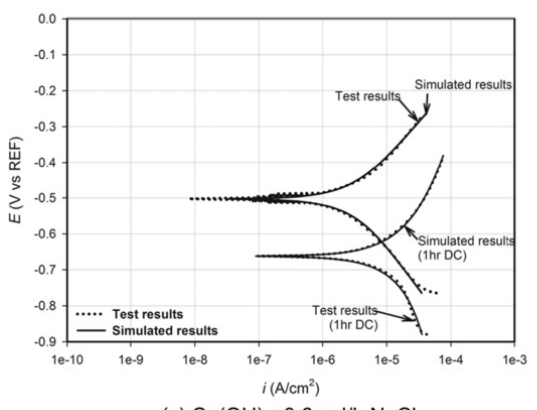

(c) $\mathrm{Ca}(\mathrm{OH})_{2}+0.6 \mathrm{~mol} / \mathrm{L} \mathrm{NaCl}$

(b) $\mathrm{Ca}(\mathrm{OH})_{2}+0.3 \mathrm{~mol} / \mathrm{L} \mathrm{NaCl}$

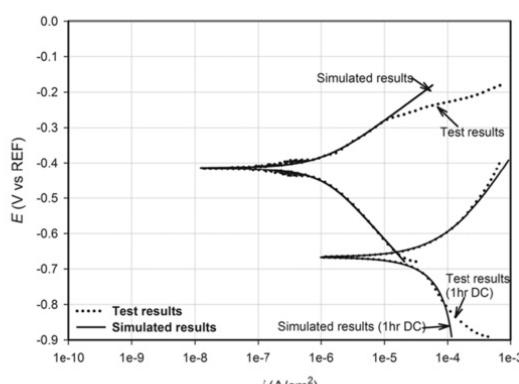

(d) $\mathrm{Ca}(\mathrm{OH})_{2}+0.8 \mathrm{~mol} / \mathrm{L} \mathrm{NaCl}$

Fig. 7 Tafel polarization results

\section{alt-text: Fig. 7}

Table 3 Tafel polarization results (0_hour $\underline{\mathrm{h}} \mathrm{DC})$,

alt-text: Table 3

\begin{tabular}{|c|c|c|c|c|c|}
\hline Electrolyte & $\begin{array}{l}E_{\text {corr }} \\
(\mathrm{mV})\end{array}$ & $\begin{array}{c}\beta_{a} \\
(\mathrm{~V} / \mathrm{dec})\end{array}$ & $\begin{array}{c}\beta_{c} \\
\text { (V/dec) }\end{array}$ & $\begin{array}{c}i_{\text {corr }} \\
\left(\mu \mathrm{A} / \mathrm{cm}^{2}\right)\end{array}$ & $\begin{array}{c}C R \\
\text { (mm/year) }\end{array}$ \\
\hline $\mathrm{Ca}(\mathrm{OH})_{2}$ & $=331$ & 0.221 & 0.134 & 0.096 & 0.001 \\
\hline $\mathrm{Ca}(\mathrm{OH})_{2}+{ }_{-} 0.3 \mathrm{~mol} / \mathrm{L} \mathrm{NaCl}$ & $-=406$ & 0.232 & 0.187 & 0.246 & 0.003 \\
\hline $\mathrm{Ca}(\mathrm{OH})_{2-}+0.6 \mathrm{~mol} / \mathrm{L} \mathrm{NaCl}$ & $-=503$ & 0.193 & 0.229 & 0.266 & 0.003 \\
\hline $\mathrm{Ca}(\mathrm{OH})_{2}+0.8 \mathrm{~mol} / \mathrm{L} \mathrm{NaCl}$ & $=415$ & 0.132 & 0.200 & 0.981 & 0.011 \\
\hline
\end{tabular}

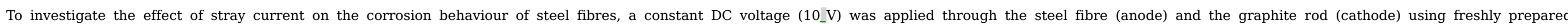




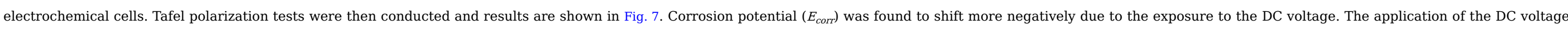

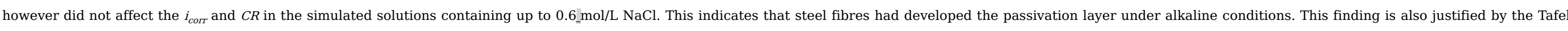

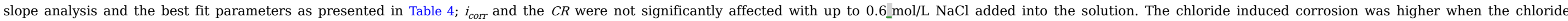

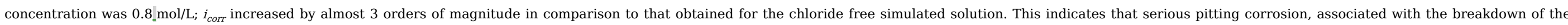

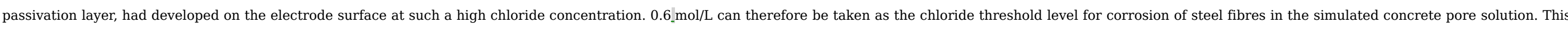

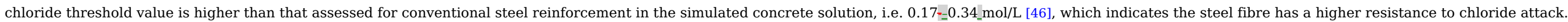

\section{Table 4 Tafel polarization results (1_hour $\underline{h}$ DC),}

alt-text: Table 4

\begin{tabular}{|c|c|c|c|c|c|}
\hline Electrolyte & $\begin{array}{l}E_{\text {corr }} \\
(\mathrm{mV})\end{array}$ & $\begin{array}{c}\beta_{a} \\
(\mathrm{~V} / \mathrm{dec})\end{array}$ & $\begin{array}{c}\beta_{c} \\
(\mathrm{~V} / \mathrm{dec})\end{array}$ & $\begin{array}{c}i_{\text {corr }} \\
\left(\mu \mathrm{A} / \mathrm{cm}^{2}\right)\end{array}$ & $\begin{array}{c}C R \\
\text { (mm/year) }\end{array}$ \\
\hline $\mathrm{Ca}(\mathrm{OH})_{2}$ & $=446$ & 0.620 & 0.159 & 0.034 & 0.0004 \\
\hline $\mathrm{Ca}(\mathrm{OH})_{2}+{ }_{-} 0.3 \mathrm{~mol} / \mathrm{L} \mathrm{NaCl}$ & $=588$ & 0.398 & 0.447 & 0.354 & 0.004 \\
\hline $\mathrm{Ca}\left(\mathrm{OH}_{2}\right)_{-}+0.6 \mathrm{~mol} / \mathrm{L} \mathrm{NaCl}$ & $-=662$ & 0.419 & 0.525 & 16.86 & 0.197 \\
\hline $\mathrm{Ca}(\mathrm{OH})_{2}+0.8 \mathrm{~mol} / \mathrm{L} \mathrm{NaCl}$ & $-=666$ & 0.283 & 0.301 & 81.44 & 0.953 \\
\hline
\end{tabular}

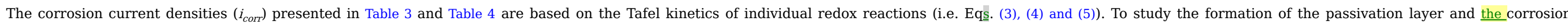

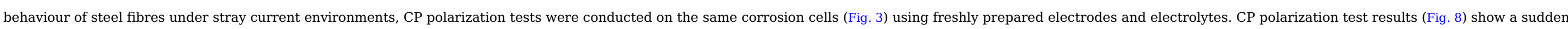

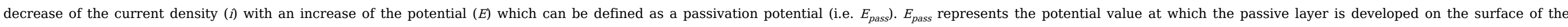

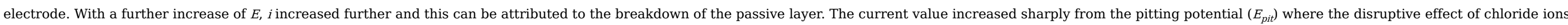

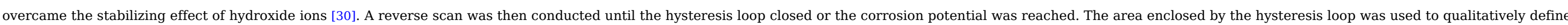

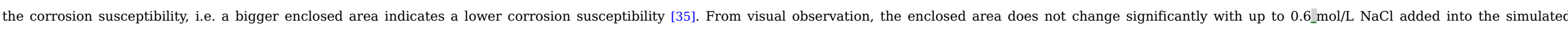

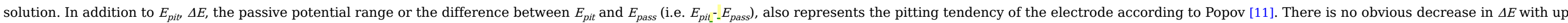

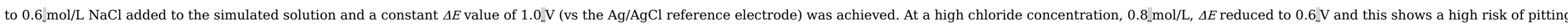

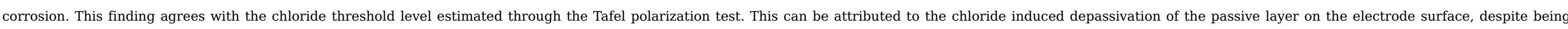

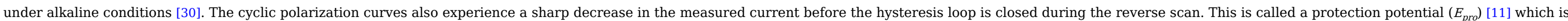
close in value to $E_{\text {corr }}$. 


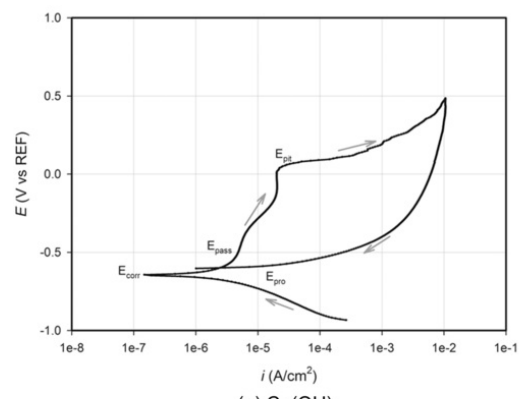

(a) $\mathrm{Ca}(\mathrm{OH})_{2}$

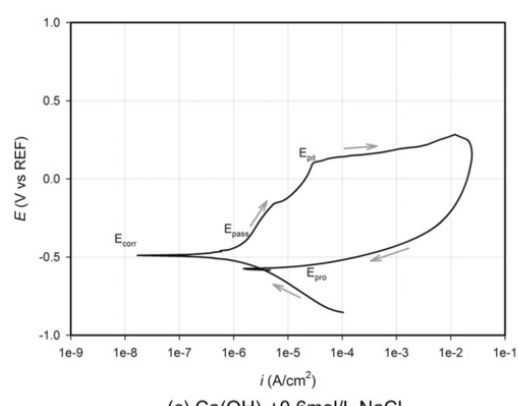

(c) $\mathrm{Ca}(\mathrm{OH})+0.6 \mathrm{~mol} / \mathrm{NaCO}$

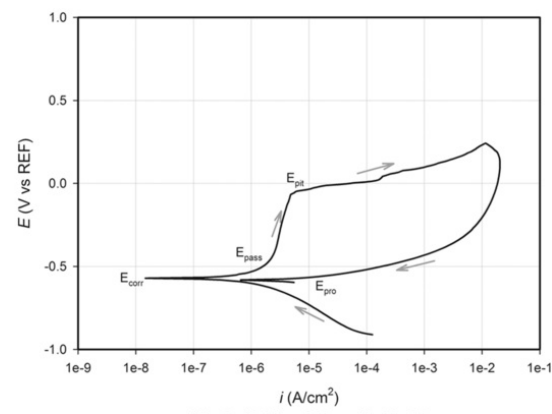

(b) $\mathrm{Ca}(\mathrm{OH})_{2}+0.3 \mathrm{~mol} / \mathrm{NaCl}$

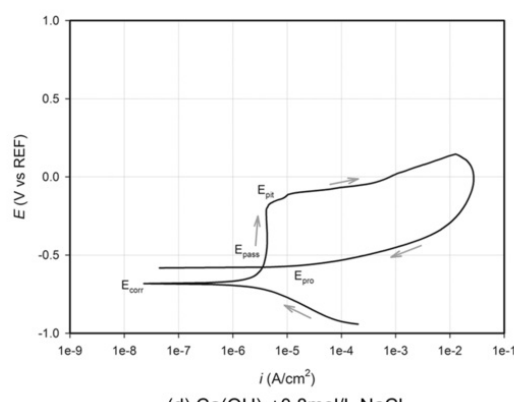

(d) $\mathrm{Ca}(\mathrm{OH})_{2}+0.8 \mathrm{~mol} / \mathrm{NaCl}$

\section{alt-text: Fig. 8}

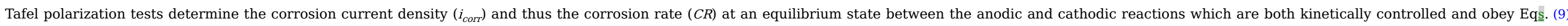

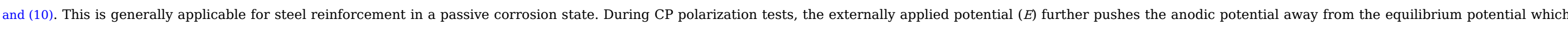

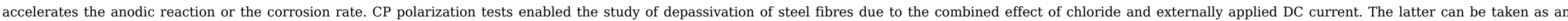
estimation of the stray current effect. A high chloride concentration, $0.8 \mathrm{~mol} / \mathrm{L}$, decreased the resistance of steel fibre to stray-current induced corrosion by reducing the $\Delta E$ value.

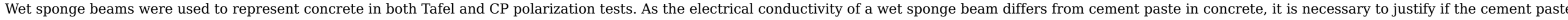

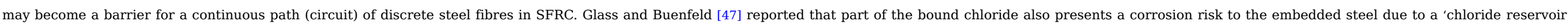

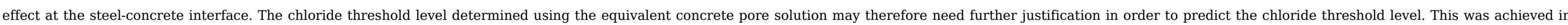
this work through the EIS investigation on steel fibres embedded in mortar specimens.

\subsubsection{Electrical conductivity of mortar (cement paste)}

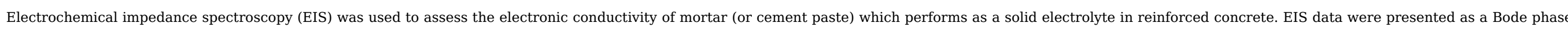

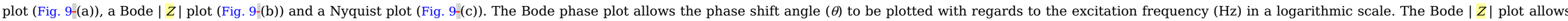

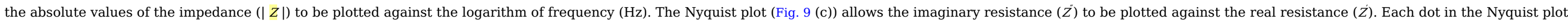
represents the impedance measured at an excitation frequency. The correlations between $|Z|, Z, Z z$ and $\theta$ are defined by Eqs. (15) and (16) [48].

$|Z|=\sqrt{\left(Z^{\prime}\right)^{2}+\left(Z^{\prime \prime}\right)^{2}}$

$\tan \theta=\frac{Z^{\prime \prime}}{Z^{\prime}}$ 


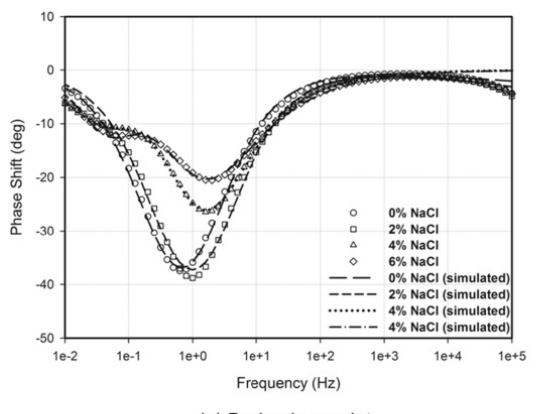

(a) Bode phase plot

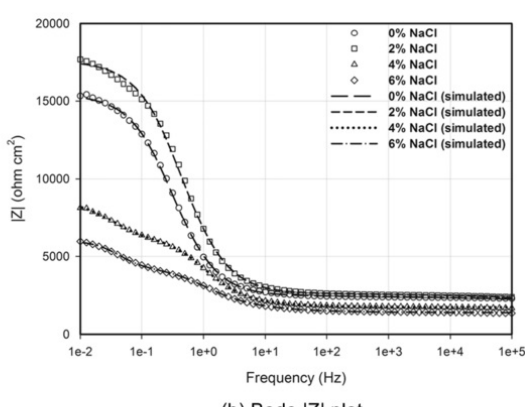

(b) Bode $|\mathrm{Z}|$ plot

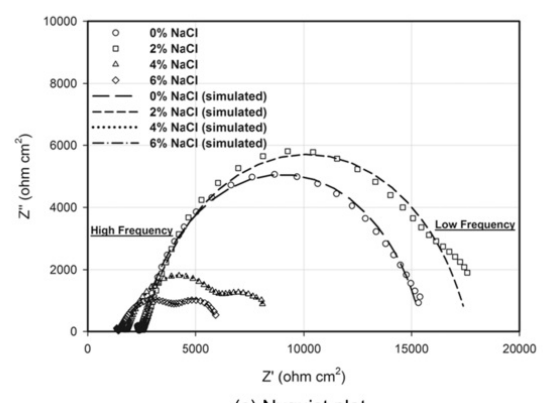

(c) Nyquist plot

Fig. 9.Fig. 9 28-day mortar EIS results.

\section{alt-text: Fig. 9}

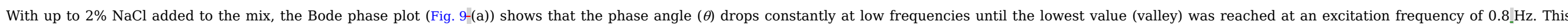

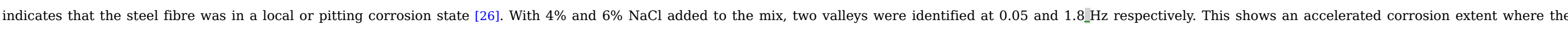

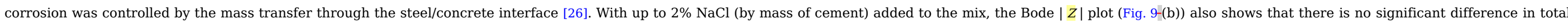
impedance, $|Z|$, especially at low frequencies. There is however a major decrease of $|\mathrm{Z}|$ from above $15,000-0 \mathrm{hm} \cdot \Omega \cdot \mathrm{cm}^{2}$ to $8 ; 000-0 \mathrm{hm} \cdot \Omega \cdot \mathrm{cm}^{2}$ at a higher $\mathrm{NaCl}$ content of $4 \%$.

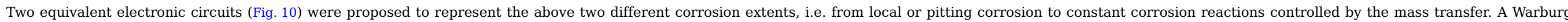

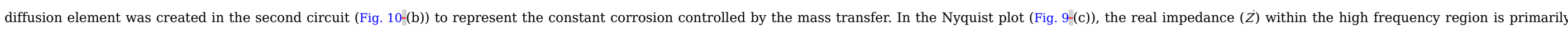

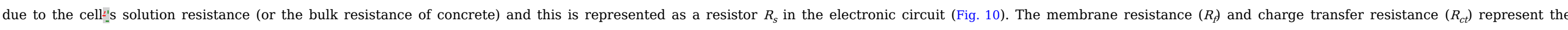

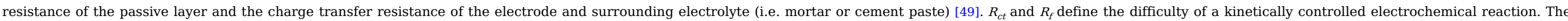

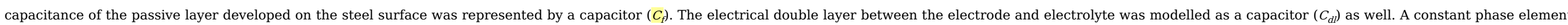

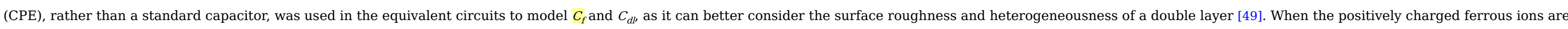
diffused into the solution as a result of the electrolysis reactions, they may affect the conductivity of the whole system by creating a diffusion barrier [50]. 


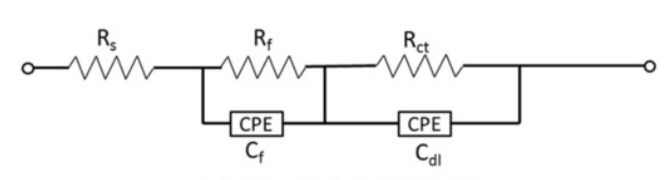

(a) Circuit A ( $\leq 2 \% \mathrm{NaCl}$ )

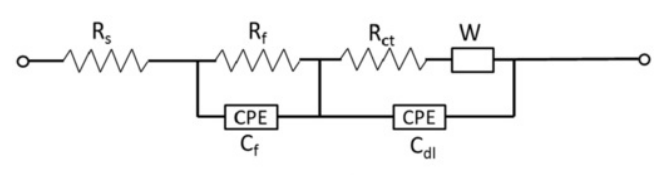

(b) Circuit $\mathrm{B}(>2 \% \mathrm{NaCl})$

Fig. 10.Fig. 10 Equivalent circuit models:

alt-text: Fig. 10

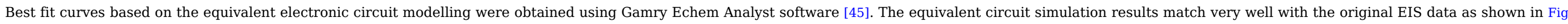

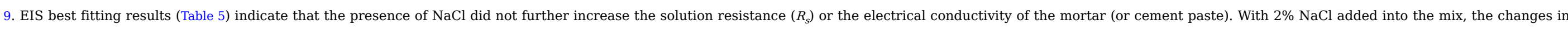

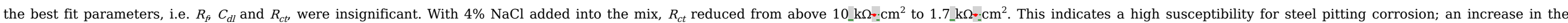

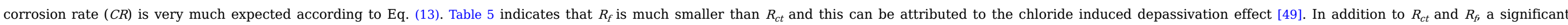

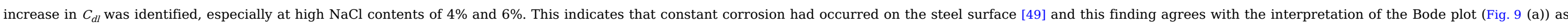

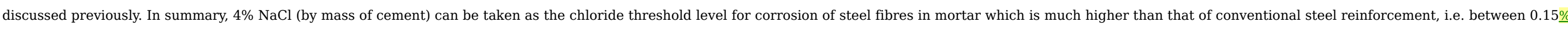
and $0.6 \%$ [31]. Mortar, as a solid electrolyte, also led to a better corrosion resistance to chloride in comparison to the results obtained using the simulated concrete pore solution, as discussed in Section 3.2 .

Table 5 EIS best fitting results (28-days),

\begin{tabular}{|c|c|c|c|c|c|c|c|c|}
\hline Mortar sample & $\begin{array}{c}R_{s} \\
\left(\mathrm{k} \Omega \bullet \cdot \mathrm{cm}^{2}\right)\end{array}$ & $\begin{array}{c}R_{f} \\
\left(\mathrm{k} \Omega \cdots \cdot \mathrm{cm}^{2}\right)\end{array}$ & $\begin{array}{c}C_{f} \\
\left(10^{-=}=6 \cdot-S^{n_{-}} \cdot \mathrm{cm}^{-=2}\right)\end{array}$ & $n_{f}$ & $\begin{array}{c}R_{c t} \\
\left(\mathrm{k} \Omega \bullet \cdot \mathrm{cm}^{2}\right)\end{array}$ & $\begin{array}{c}C_{d l} \\
\left(10^{-=}={ }^{6} \cdot-\mathrm{S}^{\mathrm{n}} \cdot-\mathrm{cm}^{-=}{ }^{2}\right)\end{array}$ & $n_{d l}$ & $\begin{array}{c}W \\
\left(10^{-=}={ }^{3} \mathrm{SE} \cdot \cdot \mathrm{s}^{1 / 2} \cdot \mathrm{Cm}^{-}={ }^{2}\right)\end{array}$ \\
\hline $0 \% \mathrm{NaCl}$ & 1.5 & 1.0 & 6.4 & 0.29 & 13.0 & 57.5 & 0.84 & $=$ \\
\hline $2 \% \mathrm{NaCl}$ & 0.99 & 1.6 & 1.4 & 0.34 & 15.0 & 38.1 & 0.83 & -z \\
\hline $4 \% \mathrm{NaCl}$ & 1.7 & 2.4 & 65.6 & 0.99 & 6.0 & 331.8 & 0.45 & 20.4 \\
\hline $6 \% \mathrm{NaCl}$ & 1.4 & 0.9 & 120.1 & 1.00 & 5.0 & 312.0 & 0.41 & 40.7 \\
\hline
\end{tabular}

\section{4.}

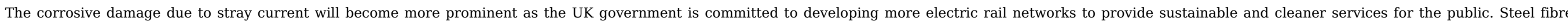

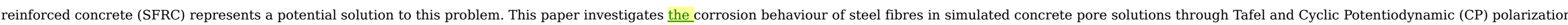

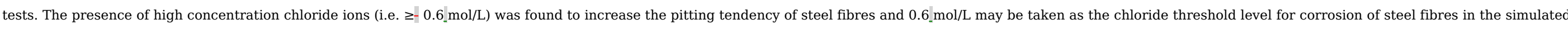

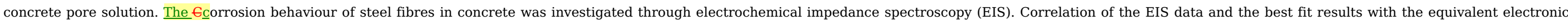

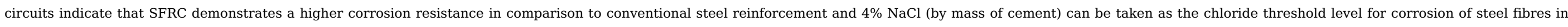
concrete.

\section{References}


[1] R. Kemp, Traction energy metrics, In: Rail Safety and Standards Board, 2007, Lancaster University; UK.

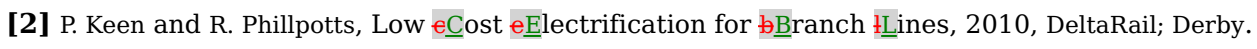

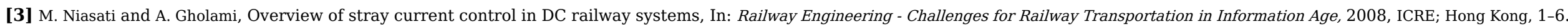

[4] W. Li, The monitor and control system of stray current corrosion in metro, In: Urban Mass Transit, 6, 2003, 48-52.

[5] L. Bertolini, M. Carsana and P. Pedeferri, Corrosion behaviour of steel in concrete in the presence of stray current, Corrosion SeienceCorros. Sci. 49, 2007 , 1056-1068.

[6] P. Vernon, Stray-current corrosion control in metros, Proc. Inst. Civ. Eng. 80, 1986, 641-650.

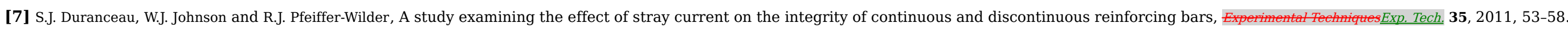

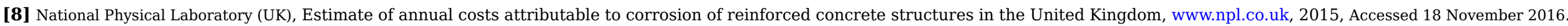

[9] BSI, BS EN 50122-2:2010 Railway Applications - Fixed Installations - Electrical Safety, Earthing and the Return Circuit, 2010, British Standards Institution

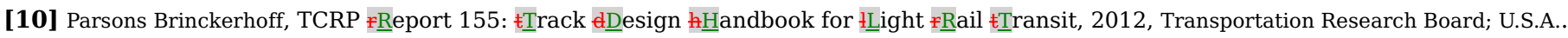

[11] B. Popov, Corrosion Engineering: Principles and Solved Problems, 2015, Elsevier Science Ltd.

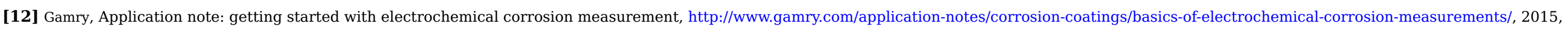
Accessed 2 April 2016.

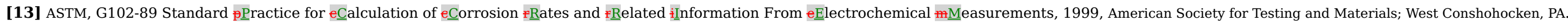

[14] Metrohm, Autolab application note part 2: measurement of corrosion rates, http://www.ecochemie.nl/Applications/, 2011, Accessed 1 December 2016.

[15] J. Wang, Analytical eElectrochemistry, 2000, Wiley-VCH; New York, USA.

[16] C. Cao, Principles of eElectrochemistry of eçorrosion, 2008, Chemical Industry Press; Beijing, China.

[17] A.C. Fisher, Electrode Dynamics (Oxford Chemistry Primers), 1996, Oxford University Press.

[18] M. Stern and A.L. Geary, Electrochemical polarization I. a theoretical analysis of the shape of polarization curves, Electrochem. Soc. $104,1957$.

[19] D.G. John, P.C. Searson and J.L. Dawson, Use of AC impedance technique in studies on steel in concrete in immersed conditions, British Corrosion JournaiBr. Corros.J. 16, 1981, 102-106.

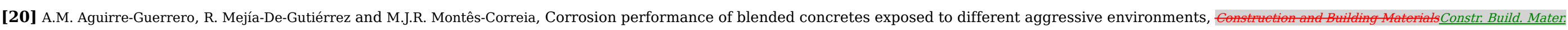
121, 2016, 704-716.

[21] S. Ahmad, M.A.A. Jibran, A.K. Azad and M. Maslehuddin, A simple and reliable setup for monitoring corrosion rate of steel rebars in concrete, Sci. World J. 2014, 2014.

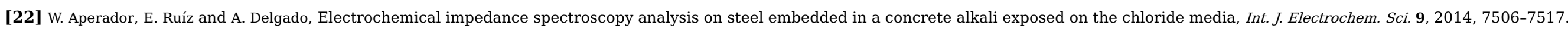

[23] B. Dong, Q. Qiu, J. Xiang, C. Huang, F. Xing and N. Han, Study on the carbonation behavior of cement mortar by electrochemical impedance spectroscopy, Materials 2014, 2014, 218-231.

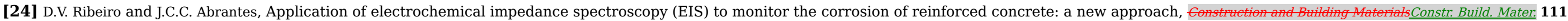
2016, 98-104.

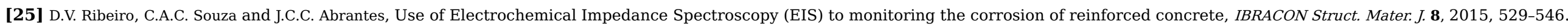

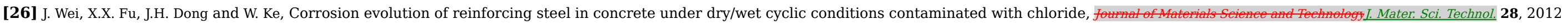
905-912. 


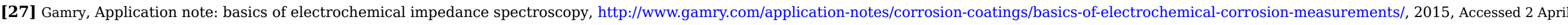
2016.

[28] Metrohm, Autolab application note EIS01: electrochemical impedance spectroscopy (EIS), http://www.ecochemie.nl/Applications/, 2011 , Accessed 1 December 2016.

[29] A.M. Neville, Properties of eçoncrete, 2011, Pearson Education Limited; England.

[30] M. Saremi and E. Mahallati, A study on chloride-induced depassivation of mild steel in simulated concrete pore solution, Eement and Cencrete ResearehCem. Concr. Res. 32, 2002, 1915-1921.

[31] ACI, Building Code Requirements for Structural Concrete (ACI 318-08) and Commentary, 2008, American Concrete Institute; Farmington Hills, U.S.A..

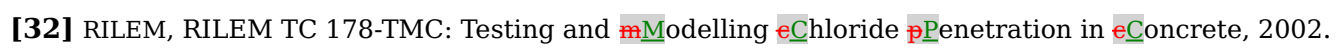

[33] X. Wan, F.H. Wittmann, T. Zhao and H. Fan, Chloride content and pH value in the pore solution of concrete under carbonation, J. Zheijang Univ. 14, 2012, 71-78.

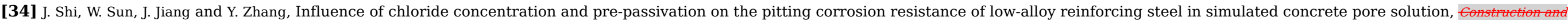
Building Materialsconstr. Build. Mater. 111, 2016, 805-813.

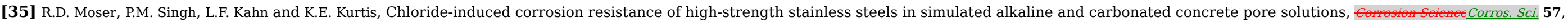
2012, 241-253

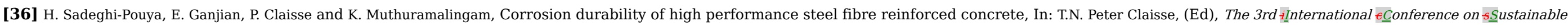

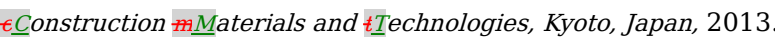

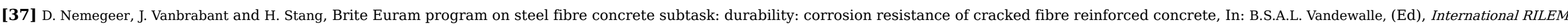
Workshop on Test and Design Methods for Steel Fibre Reinforced Concrete, 2003, RILEM Publications SARL, 47-66.

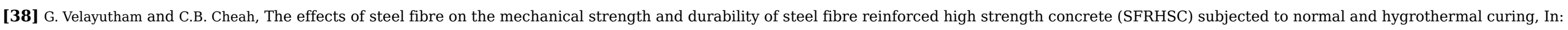
Building Surveying and Technology Undergraduate Conference, BUSTUC 2013, May 31, 2013-June 1, 2013, 2014, EDP Sciences; Langkawi, Malaysia.

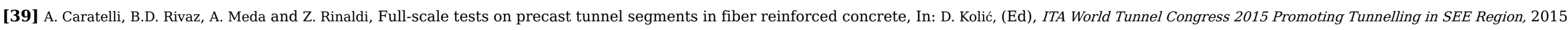
UBITG; Dubrovnik, Croatia.

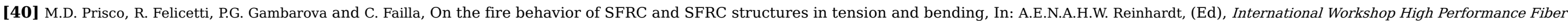
Reinforced Cement Composites, 2003, RILEM Publications SARL, 205-220.

[41] M. Burgess and H. Davies, Channel tunnel rail link section 2: Thames tunnel, Proc. Inst. Civ. Eng. Civ. Eng. 160, 2007, 14-18.

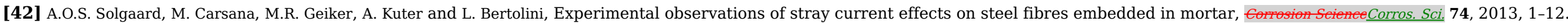

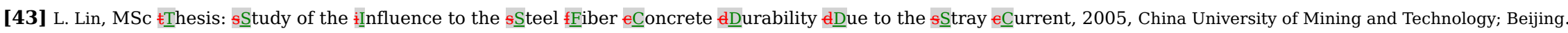

[44] BSI, BS EN 197-1:2011 Cement Part 1: Composition, Specifications and Conformity Criteria for Common Cements, 2011, British Standards Institution.

[45] Gamry, Gamry Echem Analyst 6.32, U.S.A., 2016.

[46] U. Angst, B. Elsener, C.K. Larsen and Ø. Vennesland, Critical chloride content in reinforced concrete - a review, Cement Res. 39, 2009, 1122-1138.

[47] G.K. Glass and N.R. Buenfeld, The presentation of the chloride threshold level for corrosion of steel in concrete, Eorrosion SeienceCorros. Sci. 39, 1997, 1001-1013.

[48] Gamry, Physical Electrochemistry \& Equivalent Circuit Elements, (in, U.S.)2016. 


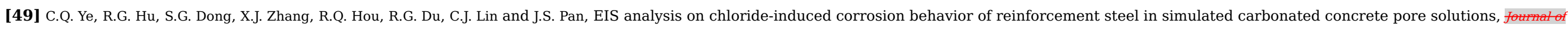
Electroanalytical Chemistry. Electroanal. Chem. 688, 2013, 275-281.

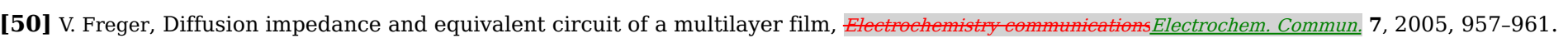

\section{Highlights}

- Formation of stray-current and its effect on the corrosion behaviour of steel fibre reinforced concrete;

- The use of simulated concrete pore solutions as the electrolyte to investigate the corrosion behaviour of steel reinforcement in concrete;

\section{Queries and Answers}

\section{Query:}

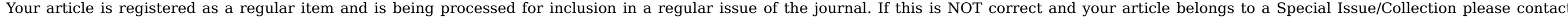
v.william@elsevier.com immediately prior to returning your corrections.

Answer: Yes

Query:

Please confirm that given names and surnames have been identified correctly and are presented in the desired order, and please carefully verify the spelling of all authors' names.

Answer: Yes

Query:

The author names have been tagged as given names and surnames (surnames are highlighted in teal color). Please confirm if they have been identified correctly.

Answer: Yes

Query:

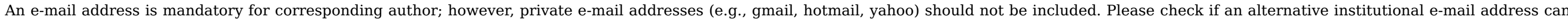
be provided for the corresponding author.

Answer: Can I use both my gmail and university email addresses? Thanks! kangkangtang@gmail.com; k.tang@wlv.ac.uk

Query:

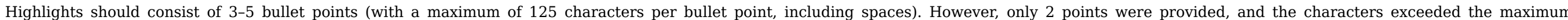
requirement. Kindly provide the necessary corrections. For more information, please see the Guide for Authors.

Answer: Formation of stray-current and its effect on the corrosion behaviour of conventional steel reinforced concrete

The use of simulated concrete pore solutions to investigate the corrosion behaviour of steel fibre reinforced concrete;

The pitting tendency of steel fibres in steel fibre reinforced concrete (SFRC). 
Query:

Please check if the captured keywords are correct and amend as necessary.

Answer: The first key word shall be "Steel fibre reinforced concrete" 